\title{
ESENSI BAHASA DALAM KAJIAN STRUKTURAL
}

\section{LANGUAGE ESSENCE IN STRUCTURAL STUDY}

\author{
Masayu Gay \\ STKIP Kie Raha Ternate, Maluku Utara \\ Jalan STKIP Kie Raha Ternate, Kota Ternate Selatan, \\ Tlp./Faks.: (0921) 3120022 \\ Pos-el: masayugay@stkipkieraha.ac.id
}

\begin{abstract}
Abstrak
Tulisan ini mendeskripsikan esensi bahasa melalui pendekatan struktural Ferdinand de Saussure, Hjemslev, dan Bloomfield. Ulasan konsep pemikiran dilakukan secara deskriptif dengan metode pustaka. Sumber kajian dari buku primer dan sekunder, serta artikel nasional dan internasional. Bentuk-isi pada dikotomi ini pada tataran epistemologi dan aksiologi. Saussure mengungkapkan esensi bahasa dari tiga hal, yakni (1) bentuk-isi, yang merupakan klasifikasi mengenai pikiran dan benda-benda/objek; (2) bentuk-ekpresi,terkait pengelompokan yang bersifat abstrak atau bayangan bunyi-bunyi dan bentuk bahasa; (3) isi-ekpresi, merupakan pembentukan dari keduanya. Hjemslev menggambarkan bentuk-isi sebagai faktor dari tanda yang umum untuk bahasa yang berbeda: bentuk-isi dilihat sebagai tipe 'makna' yang bisa dijadikan dasar untuk membandingkan tanda berbeda dalam bahasa yang berbeda. Bentuk-isi didefinisikan hanya kaitannya dengan fungsi tanda, seperti isi-ekspresi. Bentuk-isi adalah bentuk yang bersamaan dengan bentuk-ekspresi, dan merupakan unit yang berfungsi sebagai tanda dalam bahasa. Dari sudut pandang maksud, bentuk konten bersifat arbitrer. Hjemslev mengembangkan konsep hubungan tanda dan pananda. Bloomfield berangkat dari pandangan behaviorisme, sehingga ujaran manusia dapat dijelaskan dengan kondisi-kondisi eksternalnya dengan mechanism. Esensi bahasa sebagai bentuk-ekpresi terlihat sangat radikal. Bloomfield membangun bahasa yang bersifat empirisme di atas substansi. Esensi bahasa merupakan realitas struktur empiris sebagai sarana ekspresi menusia.
\end{abstract}

Kata kunci: Esensi bahasa, struktural

\begin{abstract}
This paper describes the essence of language through structural approaches Ferdinand de Saussure, Hjemslev, and Bloomfield. The concept of thinking review is done descriptively by library method. Study sources from primary and secondary books, as well as national and international articles. The contents of this dichotomy are at the epistemological and axiological level. Saussure expresses the essence of language from three things, namely (1) forms-content, which is the classification of the mind and objects/objects; (2) forms of expression, related to abstract groupings or images of sounds and forms of language; (3) content-expression, is the formation of both. Hjemslev describes the form-content as a factor of the common sign for different languages: the forms are viewed as 'meaning' types which can be used as a basis for comparing different marks in different languages. The forms are defined only in relation to the function of the sign, such as content-expression. The forms are forms that coincide with the formexpression, and are units that function as signs in language. From the point of view of intent, the form of content is arbitrary. Hjemslev developed the concept of sign and sign relationships. Bloomfield departs from a view of behaviorism, so that human speech can be explained by its external conditions with the mechanism. The essence of language as an expression-form looks very radical. Bloomfield builds empirical language on substance. The essence of language is the reality of the empirical structure as a means of human expression.
\end{abstract}




\section{Pendahuluan}

Berbicara masalah esensi bahasa tidak dapat dipisahkan dengan filsafat, sebab kajian mengenai hakikat bahasa muncul setelah para filsuf menelaah filsafat. Oleh sebab itu, mengenai perkembangan gramatika (tatabahasa) menjadi bagian dari konsep bahasapara linguis. Bermula dari gramatika dari zaman Yunani, yang dikenal sebagai gramatika (tatabahasa) tradisional hingga munculnya gramatika struktural oleh Ferdinand de Saussure sebagai cikal bakal munculnya gramatika yang lain. Mengingat fokus kajian esensi bahasa struktural Ferdinand de Saussure, Hjemslev, dan Bloomfield, maka pandangan filosofisnya menjadi substansi untuk memaknai konsep berpikirnya. Dengan demikian, tidak menimbulkan kebingungan memahami tulisan ini.

Filsafat bahasa sebagai salah satu cabang filsafat memang mulai dikenal dan berkembang pada abad XX ketika para filsuf mulai sadar bahwa terdapat banyak masalah masalah dan konsep filsafat baru dapat dijelaskan melalui analisis bahasa, karena bahasa merupakan sarana yang vital dalam filsafat (Davis, 1976). Hal ini menandakan bahwa filsuf dalam melihat hakikat realitas objek, bahasa dijadikan sebagai metode untuk memecahkan pertanyaan-pertanyaan filosofis terutama terkait dengan hakikat bahasa itu sendiri.

Perkembangan dunia filsafat dan logika sejak zaman Yunani dan Romawi, ikut berpengaruh pada kajian tentang bahasa. Bahasa dilihat para filsuf sebagai objek kajian dalam filsafat dan logika, sehingga bahasa menjadi alat utama dari filsafat (Hidayat, 2016:31). Di situlah dasar pijak berpikir para kaum Sofis, Plato, dan Aristoteles mulai berspekulasi tentang bahasa dengan pradigmanya dan pendekatannya masingmasing.

Plato merumuskan kata kerja (verba), sebagai kata yang menyatakan suatu tindakan atau kejadian.Salah satu pertanyaan mendasar dan sangat filosofis Plato adalah "apakah ada hubungan penting (logis) antara kata yang kita pakai dan acuan-acuannya. Nampaknya 'iya'. Pandangan ini berbeda muridnya dengan Aristoteles yang mengatakan bahwa hubungan antara kata (words) dan arti (meaning) merupakan persoalan konvensi (Alwasilah, 2011:26). Masalah mendasar kebahasaan lain yang menjadi titik tolak perbedaan pandangan pada kalangan filsuf, yakniantara bahasa bersifat alami (fisis) dan bersifat konvensi (nomos).

Rupanya perdebatan mengenai esensi bahasa ini berlanjut hingga awal abad XX. Hal inilah yang melahirkan aliran baru dalam Ilmu Bahasa, yang disebut gramatika struktural. Aliran yang dipelopori oleh Ferdinand de Saussure yang termuat dalam bukunya Course de Linguistique General. Menurut teori struktural, bahasa dapat didefinisikan sebagai suatu sistem tanda arbitrer yang konvensional. Berkaitan dengan ciri sistem, bahasa bersifat sistematik dan sistemik (Suparno, 2002:1). Aliran ini memandang bahasa sebagai suatu sistem yang bebas. Oleh sebab itu, pendekatan struktural berusaha mendeskripsikan suatu bahasa berdasarkan ciri-ciri khas yang dimiliki oleh bahasa itu.

Berdasarkan tinjauan terhadap perkembangan sejarah filsafat bahasa, diketahui bahwa para filsuf melihat bahasa sebagai objek dalam memecahkan dan menjelaskan konsep-konsep dalam filsafat. Abad XX kesadaran filsuf akan pentingnya bahasa dalam menjelaskan konsep-konsep filsafat. Bahasa mengungkapkan berbagai macam pernyataan filosofis, seperti 'kebenaran', 'keadilan', 'kewajiban', 'kebaikan', dan pernyataan-pernyataan fundamental filosofis lainnya. Dari sinilah para ahli filsafat menyebutkan dengan pengertian 'Filsafat Analitik' dan 'Filsafat Analitika Bahasa'. Hidayat (2016:31), para filsuf melihat bahasa sebagai objek kajian dalam filsafat dan logika, sehingga bahasa dijadikan alat utama dari kajian filsafat.

Filsafat analitika bahasa dianggap baru berkembang dan dikenal pada abad XX. Walapun dalam menjelaskan konsep-konsep 
filsafat dalam kenyataan sejarah sudah berlangsung sejak zaman Yunani. Misalnya, Socrates telah menggunakan metode analitika bahasa dalam berdebat dengan kaum Sofis yang dikenal dengan metode dialektis-kritis. Begitu pula filsuf Thomas Aquinas pada abad pertengahan melalui analisis bahasa analogi metaphor untuk menjelaskan konsep-konsep filosofisnya. Bahkan filsuf abad modern, Rene Decrates menjelaskan konsep-konsepnya melalui analisis bahasa.

Seiring perkembangannya pada abad XX filsafat analitika bahasa menemukan bentuk yang memusatkan pada analisis konsep-konsep filsafat melalui analisis penggunaan ungkapanungkapan bahasa. Filsafat yang dicetuskan George Edward Moore (1873-1958), ini lahir sebagai reaksi atas kekacauan filsafat bahasa (Kaelan, 2004:133).

Tulisan ini mendeskripsikan mengkaji bahasa dalam pendekatan struktural Ferdinand de Saussure, Hjemslev, dan Bloomfield. Ulasan konsep pemikiran dilakukan secara deskriptif dengan metode pustaka. Perlu ditegaskan bahwa kajian bahasa dalam tulisan ini lebih kepada filosofisnya. Oleh sebab itu, maka penulis menggunakan kata "esensi", bukan "hakikat", walaupun secara semantik berbeda. Namun, esensi lebih ke paradigma filosofisnya. Sumber kajian dari buku primer dan sekunder, serta artikel nasional dan internasional. Untuk memahami konsep pemikiran para penganut strukturalis memang harus berawal dari dikotomi linguistik (gramatika) sebelumnya. Oleh sebab itu, kajian ini menyinggung pula gramatika sebelumnya (tradisional). Lalu, membatasi hanya pada konsep struktural saja.

Kajian struktural menjadi penting, sebab dari sini lahirlah kajian-kajian bahasa secara fungsional dan seterusnya. Namun demikian, kajian setelahnya menjadikan kajian struktural ini sebagai pijakannya. Terutama dikotomi gramatika Ferdinand de Saussure.

Tulisan ini bermanfaat bagi pengajar bahasa (dosen dan guru), mahasiswa, praktisi bahasa, dan lembaga-lembaga terkait.

Kajian mengenai esensi bahasa semakin mengalami kemajuan ketika munculnya Ferdinand de Saussure dengan gagasan yang menggetarkan kajian filsafat dengan pengaruhnya yang cukup luas hingga ke Amerika. Konsep yang diperkenalkan Saussure, yakni pertama, langage, langue, dan parole. Kedua, pendekatan sinkronis ini muncul sebagai reaksi atas pendekatan diakronis pada abad XIX (Saussure, 1993:1011). Maksan \& Ermanto (2011:14) menambahkan, pemisahan telaah bahasa secara sinkronik dan diakronik dianggap sangat baru sewaktu zaman Sasussure. Diakronis, mengandung makna 'menelusuri waktu'. Contohnya, mengkaji perkembangan bahasa Indonesia (dahulu disebut bahasa Melayu) yang dimulai dengan kajian dan analisis Prasasti Kedukan Bukit hingga sekarang, (Kaellan, 2009:190-192). Ketiga, konsep yang dikenal sebagai Signifier (penanda) dan Signified (petanda).

Menurut pandangan Saussure, tanda bahasa "menyatukan konsep dan citra aksutis, bukan benda dan nama... . Jadi, merupakan wujud psikis dengan dua muka." Keempat, konsep sitagmatik dan paradigmatik. Istilah 'asosiatif' dalam linguistik sudah diganti dengan istilah paradigmatis, atas saran pengikut Saussure, Louis Hjelmslev, linguistik Denmark). Menurut Saussure, bentuk-bentuk bahasa dapat diuraikan secara cermat dengan meneliti hubungan asosiatif (atau paradigmatis) dan hubungan sintagmatis itu. Keenam, perbedaan valensi, isi, dan pengertian (Saussure, 1993:12).

Menurut (Chao, 1968), bahasa adalah sistem perilaku vokal kebiasaan konvensional yang anggota komunitas berkomunikasi satu sama lain. Ini memiliki karakteristik, yakni (a) bahasa adalah perilaku sukarela; (b) bahasa adalah seperangkat kebiasaan; (c) bahasa sebagai bentuk komunikasi (dalam arti paling luas); (d) bahasa adalah konvensi, tradisi, lembaga sosial, yang telah tumbuh melalui kehidupan bersama sejumlah besar orang yang menjalankan tradisi; (d) seperti lembaga sosial lainnya, bahasa konservatif dan menolak perubahan; (e) bahasa bersifat linier; (f) setiap bahasa terdiri dari persediaan yang sangat kecil serta suara khas, disebut fonem; (g) bahasa bersifat sistematis, teratur, dan tidak 
beraturan; dan (h) bahasa dipelajari, bukan bawaan; itu diserahkan, tidak diwariskan.

Dikotomi linguistik oleh Chao terdiri dari empat bagian, yakni (1) Synchronic and diachronic: Linguistik sinkronis adalah penelitian bahasa pada waktu tertentu, sedangkan linguistik diakronis adalah belajar bahasa melalui periode yang berbeda dalam sejarah. Itu Perbedaan terkadang dibicarakan sebagai yang deskriptif dan linguistik historis; (2) Descriptive and prescriptive: Dalam arti lain deskriptif berbeda dengan preskriptif, atau normatif. Ilmu bahasa menceritakan bahasa apa, bahasa apa yang ada, dan bagaimana mereka memiliki jadilah begitulah adanya; (3) Pure and applied: Bila kita tahu apa, kita lebih siap untuk memikirkan apa yang benar dan salah Itulah salah satu aspek linguistik terapan Studi bahasa asing juga sangat penting bidang linguistik terapan; dan (4) Continuous and discrete: Sudah jelas semuanya ada di dalamnya bahasa memiliki derajat vokal dan nada membentuk spektrum yang terus menerus (Chao, 1968).

Jika filsafat kerjanya bertanya secara kritis untuk mencari jawab tentang suatu realitas, maka banyak sekali pertanyaan yang harus dijawab oleh filsafat. Termasuk apa kerja dan fungsi filsafat terhadap bahasa? Pertanyaan ini layak untuk dijawab, sebab bahasa itu sendiri merupakan realitas yang membutuhkan jawaban filsafat. Sebagai contoh, berikut ini akan dikemukakan beberapa masalah kebahasaan yang memerlukan analisis atau kerja filsafat dalam memahami dan memecahkannya, antara lain: Masalah "bahasa"e pertama dan yang mendengar adalah apakah hakikat bahasa itu?

Mengapa bahasa itu harus ada pada manusia dan merupakan ciri utama manusia. Apa pula esensi manusia itu, dan bagaimana hubungan antara "bahasa"e dengan "manusia"e itu? Apakah perbedaan utama antara "bahasa" manusia dengan "bahasa" di luar manusia, seperti bahasa binatang dan atau bahasa makhluk lain. Apa persamaannya dan apa pula perbedaannya. Apa yang dimaksud dengan bahasa yang bermakna dan bahasa yang benar itu. Adapula kriteria kebenaran bahasa itu. Apa hubungan antara bahasa dengan akal, dan juga apa hubungannya antara bahasa dengan hati, intuisi dan fenomena batin manusia lainnya.

Bisakah manusia berhubungan dengan bahasa-bahasa di luar manusia. Bahasa apa yang digunakannya, dan bagaimana kita mempelajarinya.

Sudut pandang kajian bahasa menjadi ciri para filsuf terkait esensi bahasa.Plato merumuskan kata kerja, misalnya, adalah kata yang menyatakan tindakan atau kejadian.Salah satu pertanyaan mendasar Plato tentang "apakah ada hubungan penting (logis) antara kata yang kita pakai dan acuan-acuannya. Tampaknya jawaban adalah 'ya'. Berbeda dengan Aristoteles yang mengatakan bahwa hubungan antara kata (words) dan arti (meaning) adalah persoalan konvensi (Alwasilah, 2011:26). Masalah mendasar kebahasaan lain yang menjadi titik tolak perbedaan pandangan pada kalangan linguis, yakniantara bahasa bersifat alami (fisis) dan bersifat konvensi (nomos).

Di dalam pembelajaran inovasi dan penelitian, bagi seorang pendidik maupun peneliti filsafat akan berperan sebagai alat untuk mengkaji teori-teori pendidikan, metode, dan memberikan solusi terhadap permasalahan pengajaran. Berikut ini akan dikemukakan beberapa masalah kependidikan yang memerlukan analisa filsafat dalam memahami dan memecahkannya, yaitu:

1) Masalah kependidikan yang pertama dan mendasar adalah tentang apakah hakikat pendidikan itu. Mengapa pendidikan itu harus ada pada manusia dan merupakan esensi hidup manusia. Dan apa pula hakikat manusia itu. Dan bagaimana hubungan antara pendidikan dengan hidup dan kehidupan manusia.

2) Apakah pendidikan khususnya pendidikan bahasa itu bergerak untuk membina kepribadian manusia. Apakah potensi heriditas yang menentukan kepribadian manusia itu, ataukah faktor-faktor yang berasal dari luar.

Kaitannya dengan pendidikan bahasa, filsafat sudah pasti juga mempunyai hubungan yang erat dan mempunyai peran yang penting sebagai dasar berpijak dalam menentukan apa, bagaimana, dan untuk apa bahasa itu 
diajarkan. Sebagaiman yang dikatakan oleh M. Solly Lubis bahwa tiap-tiap pengetahuan mempunyai tiga komponen yang merupakan tiang penyangga tubuh pengetahuan yang disusunnya. Komponen-komponen tersebut adalah (1) Ontologi, membahas tentang apa yang ingin kita ketahui seberapa jauh yang inginkita tahu. Maka merupakan kajian mengenai teori yang ada (reality).

Dengan kata lain ontologi menjelaskan "apa" sasaran yang dikaji oleh ilmu tersebut; (2) Epistemologi, menjelaskan bagaimana cara menyusun pengetahuan yang benar, dan basis atau landasan bagi epistemologi ilmu adlah "metode ilmiah" dengan kata lain, metode ilmiah adalah cara yangn dilakukan oleh ilmu dalam menyusun pengetahuan yang benar. Dalam kaitannya dengan pendidikan ia lebih tertuju kepada cara-cara belajar dan mengajar yang di pandang terbaik untuk mengetahui atau memperoleh kebenaran; dan (3) Aksiologi, menjelaskan "untuk apa" pengetahuan tersebut disusun. Dengan kata lain, ia terkait dengan tujuan pendidikan.

Secara sederhana kajian esensi bahasa mengalami kemajuan setelah munculnya Ferdinand de Saussure ini sebagai aliran yang menganut filsafat behavioristik. Kaum behavioristik memandang bahwa bahasa sebagai ujaran, berupa sistem tanda, bahasa merupakan faktor kebiasaan, kegramatikalan berdasarkan keumuman, level-level gramatikanya ditegakkan secara rapi, tekanan analisis pada bidang morfologi, deretan sintagmatik dan paradigmatik, analisis bahasa secara deskriptif, dan analisis strukturbahasa berdasarkan unsur langsung.

Aliran-aliran tersebut dikelompokan menurut Chaer (2012) memaparkan bahwa linguistik struturalterdiri dari (1) Ferdinan de Sausure, (2) aliran Praha, (3) aliran Glosematik, (4) aliran Firtian,(5) linguistik sistemik, dan (6) struktural Amerika Leonardo Bloomfield. Sementara itu, Parera (1991) menjelaskan, bahwa linguistik modern (teoriteori kebahasaan struktural) terdiri dari (1) Ferdinan de Saussure dari Prancis, (2) Strukturalisme kelompok Praha, Strukturalisme kelompok Inggris, dan (4) Aliran Bloomfield.
1) Ferdinand de Saussure (1857-1913) berkebangsaan Prancis, berkuliah diJerman, pernah mengajar di Paris. Beliau dijuluki sebagai Bapak Linguistik Modern. Dikotomi bahasanya dimuat dalam buku Course de Linguistique Generale. Konsep pemikirannya terkait, (1) telaah singkronik dan diakronik, (2) perbedaan langue dan parole, (3) Perbedaan signifian dan signifie, dan (4) hubungan sintagmatik dan paradigmatik.

2) Aliran Glosematik (1899-1965), dengan tokoh Louis Hjemslev dari Denmark (dipengaruhi oleh pikiran Ferdinan de Saussure). Hjemslev menjadi terkenal berkat usahanya untuk menjadikan Ilmu bahasa sebagai ilmu yang berdiri otonom, bebas dari ilmu lain, dengan peralatan, metodologis dan terminologis sendiri. Analisis bahasa dimulai dari wacana, kemudian ujaran itu dianalisi atas konstituen-kontituen yang mempunyai hubungan pragmatis dalam rangka forma (hubungan gramatika intern), substansi (kategori ekstern dari objek material) ungkapan (medium verba atau grafis) dan isi (makna).

3) Leonardo Bloomfield(strukturalis Amerika, 1930-an-1950-an), Bloomfield kelahiran Jerman. Ia meninggalkan filologi gaya Eropa Saussure dan beralih pada gerakan linguistik Amerika yang dipelopori oleh Boas. Sejak tahun 1914, Bloomfield menerbitkan karya tulisan berjudul Introduction to the Science of Linguage. Buku tersebutditulis dengan dilatarbelakangi oleh pengaruhpsikologi klasikdari Wilhelm Wundth, dan akhirnya ia pun menolak titik permulaan psikologi (psychological starting point) untukmenjelaskan bahasa, setelah meninggalkan tradisi filologi gaya Eropa. Linguistic Bloomfield berangkat dari psikologi tingkah laku yang dominan di Amerika sejak 1920. Aliran berangkat dari pandangan behaviorisme, bahwa tingkahlaku individu dapat diterangkan dan diperkirakan berdasarkan pada situasisituasi yang bebas dari faktor-faktor internal. Dengan demikian, ujaran manusia 
dapat dijelaskan dengan kondisi-kondisi eksternal yang ada di sekitar individu itu berada. Aliran dari kelompok Bloomfield, lalu menyebut teori ini sebagai mechanism, sebagai kebalikan dari mentalism.

\section{Metode}

Tulisan ini merupakan hasil kajian konseptual para linguis yang disadur dari berbagai referensi dan dielaborasi. Hasil pemikiran atau pandangan esensi bahasa dari Ferdinand de Saussure, Louis Hjelmslev, dan leonardo Bloomfield. Hjemslev sendiri adalah linguis yang dipengaruhi oleh Saussure. Konsep bahasa Hjemslev mengembangkan bahasa mempunyai empat sisi, dan bukan hanya makna dan ekspresi, tetapi juga mengembangkan bahwa bahasa mempunyai sisi bentuk, substansi, isi, dan ekpresi.

Keempat sisi ini diperoleh bentuk-isi, substansi-isi, bentuk-ekspresi, dan substansiekspresi. Dalam ulasannya disertai kajiankajian dikotomi linguis tradisional, sehingga nampak perbedaannya. Sekalipun konsep pemikiran Hjelmslev sudah pada tataran struktural modern. Untuk itu, disertai pula pandangan linguis modern, Ferdinand de Saussure dan konsep pemikiran Bloomfield dengan dikotomi bahasanya. Hal ini dimaksudkan supaya perbedaan antara dikotomi yang dikembangkan masing-masing linguis tersebut nampak secara jelas.

Konten kajian dibatasi pada kajian struktural dan tidak sesudahnya, dengan pertimbangan kajian bahasa sesudah Saussure sebetulnya embrionya adalah kajian struktural modern oleh Saussure itu sendiri. Hanya saja memang mengalami perbedaan-perbedaan pandangan lain sebagai bentuk transformasi.

\section{Pembahasan}

Berdasarkan petunjuk-petunjuk yang diperoleh melalui referensi, ternyata dapat ditarik kesimpulan, bahwa gramatika struktural mengalami berkembang dengan latarbelakang historis yang sangat panjang, serta melibatkan para tokoh-tokohdengan sudut pandang dan aliran yang sangat beragam. Dengan demikian, tulisan ini secara khusus disajikan perihal aliran-aliran linguistik gramatika struktural. Namun, hanya akan spesifik mengelaborasi gramatika struktural Ferdinand de Saussure (1857-1913) menganut paham behavioristik, Louis Hjemslev (dipengaruhi oleh Saussure) berada dalam aliran glosematik (1899-1965), dan Leonardo Bloomfield (1930-an1950-an), dan menganut filsafat behavioristik-mekanis. $\mathrm{Nah}$, bagaimana para linguis ini melihat esensi bahasa sebagai bentuk-isi, substansi-isi, bentuk-ekspresi, substansi-ekspresi diuarikan sebagai berikut.

\subsection{Bentuk-Isi}

Dikotomi teori-teori kebahasaan abad XX umumnya berpijak pada pandangan ontologis, esensi bahasa bukan sebagai suatu substansi. Namun, bahasa merupakan sistem struktur yang dapat observasi secara empirik; bahasa bukanlah suatu substansi, melainkan bahasa merupakan suatu bentuk. Bahasa diyakini bukan sebagai pikiran atau objek dari segala realitas kehidupan. Bahasa pun dianggap bukan merupakan bunyi atau gerak ekpresi setiap individu dalam bentuk bunyi ujaran. Pemikiran ini dikembangkan oleh linguis strukturalisme yang berkembang di Amerika oleh Bloomfield dan aliran yang bernama glossematik, walaupun dikotomi tersebut berakar dari konsep Ferdinand de Saussure, yang melihat bahasa bukan hanya sebagai bentuk. Saussure mengakui konsepnya mengenai signifie, yakni lambang yag merujuk pad aacuannya dan significant, yakni bentuk ujaran melalui lambang bunyi.

Saussure melihat bahasa sebagai bentuk, meliputi tiga hal (1) bentuk-isi, yakni klasifikasi mengenai pikiran dan bendabenda/objek, (2) bentuk-ekpresi, yakni terkait pengelompokan yang bersifat abstrak atau bayangan bunyi-bunyi dan bentuk bahasa. (3) isi-ekpresi, merupakan pembentukan dari keduanya. Ketiga masalah yang berhubungan dasar bentuk-isi sangat mendominasi dan mewarnai dikotomi bahasa modern, baik pada tataran epistemologinya (bagaimana proses terjadinya) maupun aksiologinya (apa kegunaannya), yang pada akhirnya melandasi analisis bahasa.

Hjelmslev menggambarkan bentuk-isi sebagai faktor dari tanda yang umum untuk bahasa yang berbeda: bentuk-isi dapat dilihat 
sebagai tipe 'makna' yang bisa dijadikan dasar untuk membandingkan tanda berbeda dalam bahasa yang berbeda. Hjelmslev mengacu pada istilah warna: untuk warna green Inggris, vert French, dan glas Welsh yang isinya adalah warna itu sendiri disebut dengan katakata berbeda dalam tiga bahasa. Pada dua ilustrasi di atas mungkin 'mengekstrak' barang yang tidak terbentuk dari kisaran ekspresi berbeda. Namun, dengan merenungkan contohnya lebih lanjut, dapat dilihat bahwa 'maksud' sendiri tidak dapat diberi label. Misalnya, dengan mengatakan bahwa dalam contoh, 'maksudnya' adalah 'saya tidak tahu' atau 'hijau', maksudnya terbentuk dalam satu atau lain cara, dan dengan cara ini dilihat dari sudut pandang bahasa tertentu, itu dilihat sebagai substansi-isi.

Bentuk-isi dapat didefinisikan hanya dalam kaitannya dengan fungsi tanda (Hjelmslev, 1963:54), seperti yang dicirikan di atas dalam hal interaksi antara sebuah isi dan ekspresi. Dengan kata lain, bentuk-isi adalah bentuk yang bersamaan dengan bentukekspresi, dan merupakan unit yang berfungsi sebagai tanda dalam bahasa. Dari sudut pandang maksud, bentuk konten bersifat arbitrer.

Konsep bahasa Hjemslev mengembangkan bahasa mempunyai empat sisi, dan bukan hanya makna dan ekspresi, tetapi juga mengembangkan bahwa bahasa mempunyai sisi bentuk, substansi, isi, dan ekpresi. Dari keempat sisi ini diperoleh bentuk-isi, bentuk-ekspresi, substansi-isi, dan substansi-ekspresi. Konsep ini merupakan pengembangan konsep hubungan antara yang ditandai dengan penandanya.

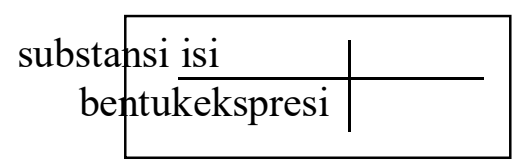

Setelah perkembangan selanjutnya, Santoso mengatakan bahwa konsep ini gagal berkembang karena sistem tanda ini masih bersifat formal dan struktural, sementara banyak konsep-konsep bahasa yang menyinggung makna dari segi sosial (Santoso, 2003). Akhirnya, 'bentuk', adalah urutan suara yang ditafsirkan dalam bahasa tertentu. Dalam hal fonem yang digunakan bahasa kemungkinan vokalisasi manusia. Sifat fonemik (formal) pada gilirannya ditentukan oleh keberadaannya terkait dengan isi. Dengan kata lain, juga di bidang ekspresi, 'bentuk' dicirikan dalam kaitannya dengan fungsi tanda: bentuk ekspresi didefinisikan dengan membentuk koneksi dengan bentuk konten dan dengan cara ini merupakan sebuah tanda.

Perlu ditekankan bahwa pengertian tersebut di dalam pembedaan form-substance didefinisikan secara intrinsik dalam kaitannya satu dengan lain. Keterkaitan antaranya terungkap dalam karakterisasi berikut: maksud menyediakan substansi untuk suatu bentuk (Hjelmslev, 1963:52). Isi berfungsi untuk 'membentuk' area konseptual yang dimaksudkan ke dalam isi-substansi karena dikaitkan dengan ekspresi isi dalam sebuah bahasa tertentu. Hal yang sama berlaku untuk bentuk ekspresi: bentuk ekspresi berfungsi untuk 'membentuk' area pembentukan bunyi menjadi bagian ekspresi berdasarkan hubungan dengan bentuk isi dalam bahasa.

Dalam teori bahasa Hjelmslev, perbedaan utama tanda linguistik adalah antara isi dan ekspresi: itu adalah hubungan antara dua hal yang abstraksi (konseptual dan bunyi), interaksi antara isi dan ekspresi merupakan sebuah tanda. Namun, perbedaan ini dipilahpilah oleh perbedaan lain, yaitu antara bentuk dan substansi. Baik isi dan ekspresi dapat dianalisis lebih lanjut dalam bentuk-substansi.

Menurut Lyons, kata bisa dianggap murni sebagai bentuk, baik lisan atau tulisan, atau, sebagai alternatif, sebagai ekpresi komposit, yang menggabungkan bentuk dan makna (Lyons, 1995).

\subsection{Substansi-Isi}

Lazimnya teori modern mengenai dikotomi bahasa tidak mengidentikan kata dengan benda. Namun, hingga kini masih ada anggapan bahwa kata dan benda memiliki kesamaan. Kata adalah bagian terkecil dari kalimat merupakan suatu unsur sistem tanda. Kata merupakan suatu penanda suatu realitas dunia dan berada di luar sistem tanda tersebut. Dalam pandangan Saussure mestinya dibedakan antara significat sebagai bentuk ekpresi melalui sistem lambang dengan 
signifie sebagai aspek semantiknya yang memiliki acuan, apakah berupa benda, manusia, binatang, konsep, maupun nilai. Hal ini tentu bertentangan dengan dikotomi yang dikembangkan oleh linguis tradisional, yang menganggap hakikat bahasa bukanlah substansi-isi.

Menurut paham tradisional kata-kata mempunyai kesesuaian dalam pikiran, sebab secara onlogis pikiranlah yang menentukan sistem lambang bahasa. Makna kata-kata merupakan proses mental manusia secara menyeluruh, maka sistem bahasa pun ditentukan cara berpikir manusia. Dikotomi linguis tradisional secara logis sistem ilmu bahasa didasarkan pada analisis secara empiris.

Substansi-isi dimaksudkan dilihat dari bahasa: substansi-isi adalah area yang dimaksudkan yang muncul, sebagai hasil dari cara spesifik di mana bahasa tertentu mengukir atau 'membentuk' maksud ini. Oleh karena itu, sebuah isi tergantung pada proses 'pembentukan' dalam sebuah bahasa. Hjelmslev menekankan fitur konten substansiisi dengan mendefinisikannya dalam kaitannya dengan bentuk-isi:

"Substansi tergantung pada bentuk sedemikian rupa, sehingga berada secara eksklusif oleh bantuannya dan sama sekali tidak bisa dikatakan memiliki eksistensi yang independen. (Hjelmslev, 1963:51)."

\subsection{Bentuk-Ekspresi}

Esensi bahasa sebagai bentuk-ekpresi lazimnya dikembangkan oleh strukturalisme yang radikal. Dengan kata lain, para linguis ini berkeinginan membangun bahasa yang bersifat empirisme di atas substansi. Pemikiran ini dikembangkan oleh Leonard Bloomfield, linguis beraliran Amerika. Namun, konsekuensi dari dikotomi ini secara ontologis didasarkan pada realitas empiris bahasa, terutama berkaitan dengan struktur bahasa yang dihasilkan. Dengan demikian, menghasikan sistem yang bersifat menyeluruh dan bisa berdiri sendiri. Bloomfield mendasari dikotominya secara ontologis, bahwa pada dasarnya bahasa merupakan realitas struktur empiris sebagai sarana ekpresi menusia. Bahasa harus dapat dinyatakan sebagai cara sistematis dan empiris agar menentukan kebenaran atas suatu kebenaran yang benarbenar objektif.

Secara struktural bahasa harus dapat dinyatakan secara fisik, sehingga analisis bunyi-bunyi ujaran sebagai sebuah fenom yang dapat dilihat secara langsung. Oleh sebab itu, menurut pandangan kaum strukturalis dengan dikotomi bentuk-ekspresi, memisahkan unsur semantik (makna) yang termaktud dalam bahasa pada disiplin ilmu lain, seperti antropologi, masalah yang berkaitan dengan psikologi, juga filsafat dan logika. Namun, sekali lagi bahwa pada bidang-bidang ilmu tersebut tidak menyediakan tempat terkait objek material bahasa. Untuk itu, apapun alasannya linguistik harus memberikan tempat agar berkembang, sebab ilmu harus dapat memberikan jawaban secara detail atas masalah-masalah kebahasaan (Mackey, 1965: 25).

Kompetensi suatu ilmu agar mengembangkan bidangnya masing-masing, guna menjawab pertanyaan mendasar pada makna bahasa, akhirnya munculah berbagai bidang ilmu antardisipliner dengan bahasa, seperti psikologi berkembang menjadi psikolingistik (cabang linguistik yang mempelajari bahasa hubungannya dengan kejiawaan), filsafat berkembang menjadi filsafat bahasa (mengkaji hakikat bahasa), sosiologis berkembanglah sosiolinguistik (cabang ilmu linguistik yang membicarakan bahasa dalam kehidupan bermasyarakat dan lain sebagainya. Bahkan, hingga sekarang ilmu bahasa menjadi penghela ilmu pengetahuan. Menurut Louis Hjemslev, bahwa bahasa sebagai bentuk-ekpresi adalah bagian yang bersamaan dengan bentuk-isi (Hjelmslev, 1963:52).

\subsection{Substansi-Ekspresi}

Dikotomi teori bahasa modern,lazimnya sudah meletakkan dasar-dasar kajian bahasa pada aspek substansi-ekspresi sebagai dasar ontologisnya. Unsur-unsur yang dikategorikan ke dalam substansi-ekspresi ini menjadi aspek kuantitas bahasa yang dianggap sebagai sistem bunyi ujaran bahasa pada setiap manusia, yang merupakan ekspresi langsung dari pikiran, perasaan serta emosi manusia. Inilah dasar- 
dasar yang merupakan sumber epistemologis pengembangan kajian ilmu bahasa terutama dalam bidang teori bunyi bahasa, yaitu fonologi (ilmu bunyi). Bahkan pada tingkatan tertentu mendudukan substansi sistem tanda bahasa ini sebagai sesuatu yang bersifat natural/alamiah, sehingga banyak teori bahasa yang mengembangkan bahasa berdasarkan pada teori fonetik. Teori ini menganggap bahwa bahasa muncul baik ditinjau dari aspek gejala fisik, yaitu berkaitan dengan fonetik akustik, sebagaimana dikembangkan oleh Fant, Zwirner, Ladefoged, Kaizer dan tokohtokoh lainnya.

Kasus yang sama juga substansi-ekspresi ini, sebetulnya ditinjau dari sudut pandang fisiologi, yakni bagaimana terjadinya bunyi ujaran atau sering disebut fonetik artikulasi sebagaimana yang dikembangkan oleh Straka Jones, Victor Fouche, dan tokoh lainnya. Banyak linguis pada bidang fonetik berpendirian bahwa bunyi dari suatu ungkapan atau ekspresi adalah merupakan dasar suatu bahasa, sehingga mereka membuat suatu deskripsi yang mendalam tentang sistem bunyi tersebut.

Konsep mengenai substansi bahasa sebagai substansi-ekspresi yang pada dasarnya substansi bahasa yang merupakan sistem bunyi merupakan dasar ontologis utama bagi deskripsi bahasa. Pengakuan pada hal ini, memang merupakan pengembangan lebih lanjut dari ilmu bahasa modern yang mendasarkan pada substansi empiris bahasa yang berupa sistem bunyi ujaran yang hakikatnya dapat diindra oleh manusia.

\section{Simpulan}

Berdasarkan hasil kajian esensi bahasa, maka disimpulkan bahwa dikotomi bahasa Saussure,Hjemslev, dan Bloomfiled sebetulnya muncul dari struktural Ferdinand de Sasussue. Namun, pada kajian selanjutnya dikotomi ini mengalami perbedaan-perbedaan sebagaimana dijelaskan sebagai berikut.

1. Ferdinand de Saussure menganut paham behavioristik. Saussure melihat bahasa sebagai bentuk, meliputi tiga hal (1) bentuk-isi, yakni klasifikasi mengenai pikiran dan benda-benda/objek, (2) bentukekpresi, yakni terkait pengelompokan yang bersifat abstrak atau bayangan bunyi-bunyi dan bentuk bahasa. (3) isi-ekpresi, merupakan pembentukan dari keduanya. Ketiga masalah yang berhubungan dasar bentuk-isi sangat mendominasi dan mewarnai dikotomi bahasa modern, baik pada tataran epistemologinya (bagaimana proses terjadinya) maupun aksiologinya (apa kegunaannya), yang pada akhirnya melandasi analisis bahasa.

2. Louis Hjemslev menggambarkan bentuk-isi sebagai faktor dari tanda yang umum untuk bahasa yang berbeda: bentuk-isi dapat dilihat sebagai tipe 'makna' yang bisa dijadikan dasar untuk membandingkan tanda berbeda dalam bahasa yang berbeda. Bentuk-isi didefinisikan hanya kaitannya dengan fungsi tanda, seperti yang dicirikan antara sebuah isi dan ekspresi. Dengan kata lain, bentuk-isi adalah bentuk yang bersamaan dengan bentuk-ekspresi, dan merupakan unit yang berfungsi sebagai tanda dalam bahasa. Dari sudut pandang maksud, bentuk konten bersifat arbitrer. Konsep Saussure inilah yang masih dipertahankan. Hjemslev mengembangkan bahasa mempunyai empat sisi, dan bukan hanya makna dan ekspresi, tetapi juga mengembangkan bahwa bahasa mempunyai sisi bentuk, substansi, isi, dan ekpresi. Dari keempat sisi ini diperoleh bentuk-isi, bentuk-ekspresi, substansi-isi, dan substansi-ekspresi. Konsep ini merupakan pengembangan konsep hubungan antara yang ditandai dengan penandanya. Perbedaan utama tanda linguistik adalah antara isi dan ekspresi: itu adalah hubungan antara dua hal yang abstraksi (konseptual dan bunyi), interaksi antara isi dan ekspresi merupakan sebuah tanda. Namun, perbedaan ini dipilah-pilah oleh perbedaan lain, yaitu antara bentuk dan substansi. Baik isi dan ekspresi dapat dianalisis lebih lanjut dalam bentuk-substansi.

3. Leonard Bloomfieldmeninggalkan filologi gaya Eropa Saussure dan beralih pada gerakan linguistik Amerika. Aliran berangkat dari pandangan behaviorisme, 
bahwa tingkahlaku individu dapat diterangkan dan diperkirakan berdasarkan pada situasi-situasi yang bebas dari faktorfaktor internal. Dengan demikian, ujaran manusia dapat dijelaskan dengan kondisikondisi eksternal yang ada di sekitar individu itu berada. Aliran dari kelompok Bloomfield, lalu menyebut teori ini sebagai mechanism, sebagai kebalikan dari mentalism. Hakikat bahasa yang dikembangkan Bloomfield sebagai bentukekpresi terlihat sangat radikal. Dengan kata lain, para linguis ini berkeinginan membangun bahasa yang bersifat empirisme di atas substansi. Namun, konsekuensi dari dikotomi ini secara ontologis didasarkan pada realitas empiris bahasa, terutama berkaitan dengan struktur bahasa yang dihasilkan. Dengan demikian, menghasikan sistem yang bersifat menyeluruh dan bisa berdiri sendiri. Bloomfield mendasari dikotominya secara ontologis, bahwa pada hakikatnya bahasa merupakan realitas struktur empiris sebagai sarana ekspresi menusia. Bahasa harus dapat dinyatakan sebagai cara sistematis dan empiris agar menentukan kebenaran atas suatu kebenaran yang benar-benar objektif.

\section{Daftar Pustaka}

Alwasilah, Chaedar, A. 2011. Beberapa Mazhab dan Dikotomi Teori Linguistik: Edisi Revisi. Angkasa: Bandung.

Alwasilah Chaedar. 2011. Beberapa Madzab dan Dikotomi Teori Linguistik. Angkasa; Bandung.

Bloomfield, Leonardo. 1995. Bahasa. (Judul asli: Language). Diterjemahkan oleh I Sutikno. Jakarta: Gramedia Pustaka Utama.

Chao, Y. R. 1968. Language and symbolic systems. CUP Archive.

Chaer, Abdul. 2012. Linguistik Umum. Jakarta:Rineke Cipta.

Davis, Steven. 1976. Philosophy and Language. The Bobbs Merrill Company, Inc., United States of America.

Hidayat, Ahmad A. 2016. Fisafat Bahasa. PT Remaja Rosda Karya: Bandung.
Hjelmslev, L. 1963. Prolegomena to A Theory of Language (terjemahan Francis $\mathrm{J}$. Whitfield). Madison: University of Wisconsin Press.

Hidayat, A. A. 2016. Fisafat Bahasa. Bandung: Remaja Rosda Karya.

Kaelan. 2002. Filsafat Bahasa: Realitas Bahasa, Logika Bahasa, Hermeneutika, dan Postmodernisme. Yogyakarta: Paradigma.

Kaelan, M.S. 2004. "Filsafat Analitis Menurut Ludwig Wittgenstein". Humaniora Vol. 16 No. 2, 133-146.

Lyons, John. 1995. Linguistic Semantic. Combridge, New York: University Press.

Lubis, M.Solly. 1994. Filsafat Ilmu dan Penelitian. Bandung: Mandar Maju.

Mackey, WF. 1965. Interferensi dua bahasa: Analisis dan pengukurannya. Jurnal Komunikasi , 15 (4), 239-249.

Kaelan. 2000. Filsafat Bahasa Semiotika dan Hermeneutika. Sleman: Yogyakarta.

Santoso, Riyadi. 2003. Semiotika Sosial: Pandangan terhadap Bahasa. Pustaka Eureka: Surabaya.

Saussure, de Ferdinand. 1993. Pengantar Linguistik Umum (judul asli: Cours De Linguistique Generale). Diterjemahkan oleh Rahayu S. Hidayat. Yogyakarta: Gajah Mada University Press.

Soeparno. 2002. Dasar-dasar Linguistik Umum. Yogyakarta: Tiara Wacana Yogya.

2013. Dasar-dasar Linguitik Umum (Edisi Revisi). Yogyakarta: Tiara Wacana. 
Lampiran 1 Tahap Perkembangan Gramatikan Tradisional

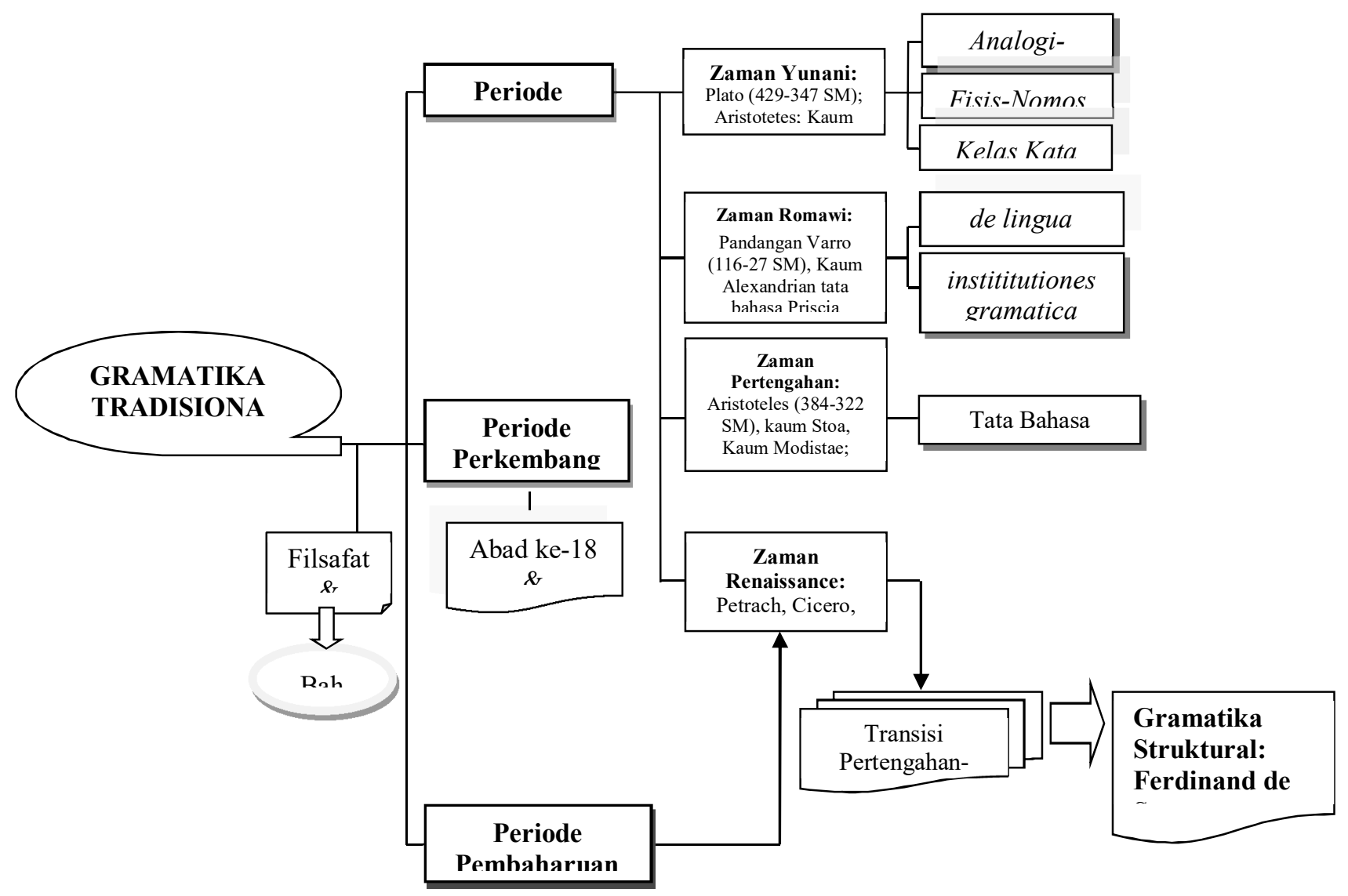




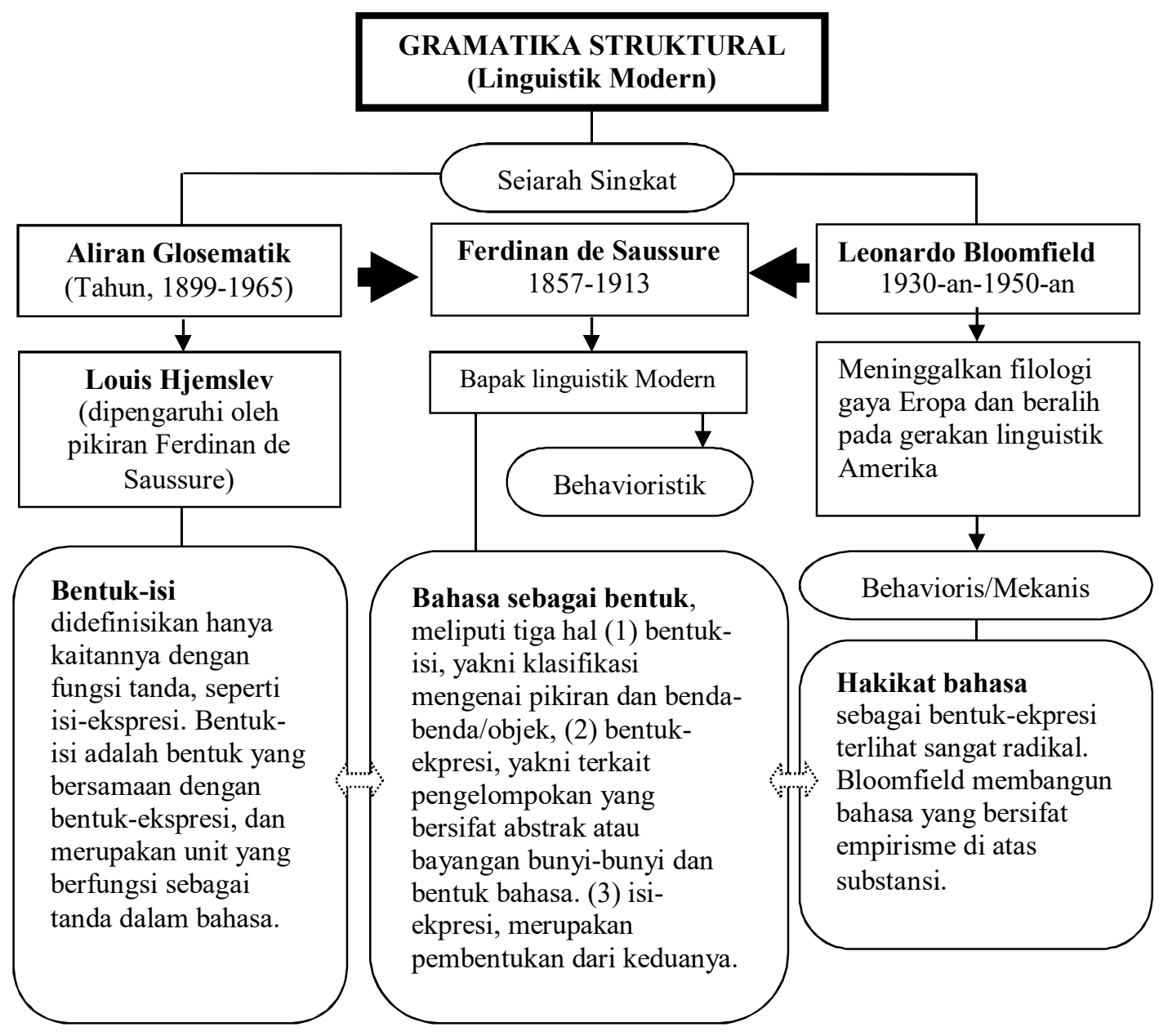

Keterangan tanda:

$\rightarrow$ : Bermula dari

: Diturunkan dari dikotomi yang semula sama

: Setelah berbeda dikotomi/mengelami perkembangan 